$\mathbb{T}$ periodica polytechnica

\author{
Social and Management Sciences \\ $18 / 1(2010) 2130$ \\ doi: 10.3311/pp.so.2010-1.03 \\ web: http://www.pp.bme.hu/so \\ (c) Periodica Polytechnica 2010
}

RESEARCH ARTICLE

\section{Uncertainty in innovation in the biotech-pharmaceutical industry}

Dávid Domonkos

Received 2010-01-14

\section{Abstract \\ Biotechnology, just like other dynamically growing branches} of industry, has been very rapidly changing. Disruptive innovations arise from time to time. Since this is a very high risk-high benefit industry, and $R \mathcal{E} D$ phases often require several hundred millions of dollars, the participants seek to minimize and share risk.

In case of biotechnology the assessment of risks (uncertainties) in the technological development is becoming an increasingly difficult task to solve. This is especially true in a rapidly changing turbulent environment, where environment and its knowledge changes from day to day, where in addition to small ones, radical innovations are typical as well. Understanding the necessary parameters is becoming more and more uncertain, thus also becoming limited. There is a huge literature on technological uncertainty just as there is on risks of financial issues.

My main problem with this is that there is a strong inclination to believe that uncertainty can always be successfully modelled by quantitative risk assessment ( $q R A)$. In contrast to this, a wide range of environmental studies puts emphasis on the nonpredictable risk. (Think of the the management consequence of non-predictability, the needed precaution.)

A small biotech company has two alternatives for survival:

finding a protected market, where, drawing on resources from outside, it can become influential, or by concentrating on cooperation, solving a partial task, working as part of a cluster, becoming an importer of knowledge.

\section{Keywords}

red biotech · biopharmaceuticals · high uncertainty · biopharma strategies

\section{Introduction}

Biotechnology, just like other dynamically growing branches of industry, has been very rapidly changing. Disruptive innovations arise from time to time. Since this is a very high risk - high benefit industry, and $R \& D$ phases often require several hundred millions of dollars, the participants seek to minimize and share risk. A small biotech company has two alternatives for survival:

1 finding a protected market, where, drawing on resources from outside, it can become influential, or

2 by concentrating on cooperation, solving a partial task, working as part of a cluster, becoming an importer of knowledge.

\section{Biotechnology and the pharmaceutical industry from a strategic point of view}

\subsection{Biotechnological innovations and trends}

Biotechnology is spreading rapidly in the pharmaceutical, environmental protection, agricultural, and other industrial environments. The number of molecules produced by biotechnological methods is growing rapidly, thanks to new methods and an almost exponentially increasing knowledge base.

The appearance of novelties is very fast. There is a significant technological leap, from time to time. These radical innovations are aimed at solving complex problems by implementing and integrating new technologies [1]. Radical innovations that lead to disruptive technological development are usually the result of long term research. These innovations can provide a broad platform for a new regime in technology [2]. At the same time, disruptive innovation is not necessarily radical. Small innovations can also have great disruptive economical influence. Just think about the turning to containers of oversee ship cargos, for example.

The development of biotechnology can be divided into several large eras [3]:

- The period started with the conscious use of biotechnology. This process started in the second half of the 19th century (about 1865), when Pasteur discovered that fermentation is caused by microorganisms. After understanding the essence 
Fig. 1. [6]: Ratio of newly registered phramaceuticals:chemical and biotech entities.

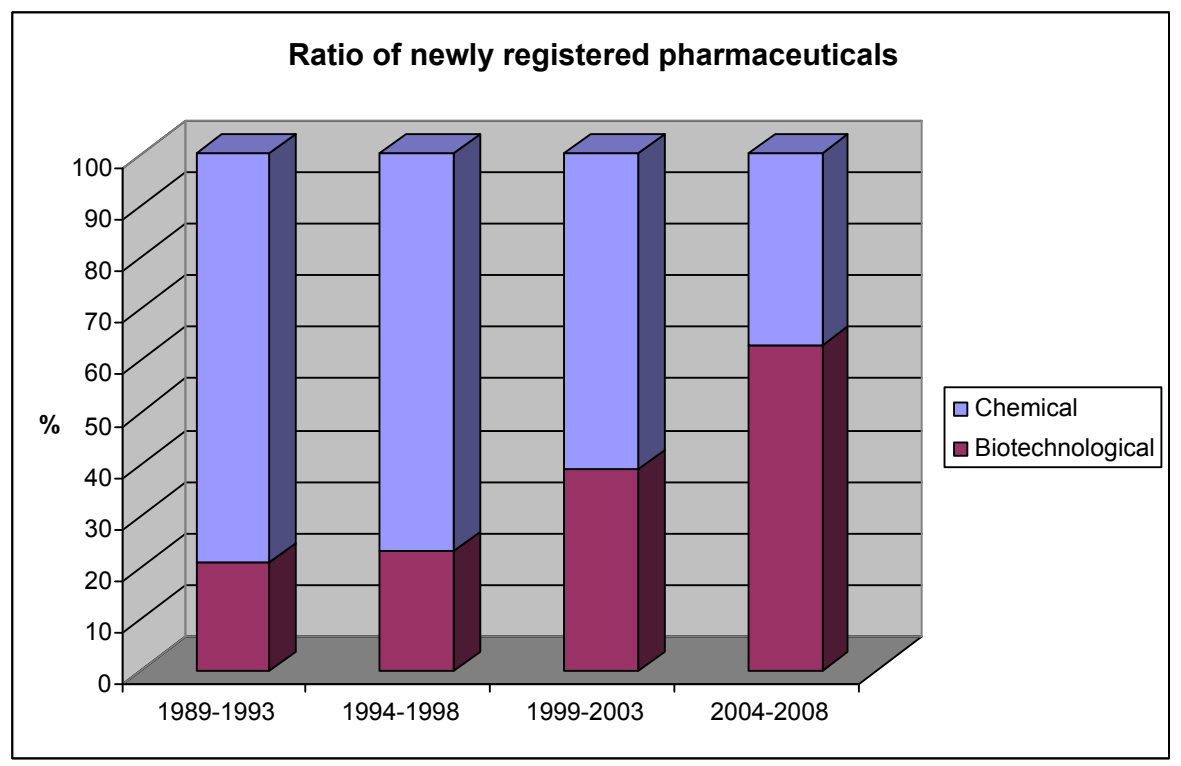

of this process through microbiology, its industrial application became feasible. The beer and alcohol industries developed, vinegar and lactic acid production began. The production of ethanol, butanol, acetone, glycerin, citric acid etc. through fermentation began.

- The discovery of antibiotics provided the momentum for the second great leap around 1940. The productivity of microorganisms was increased by biological, genetic and biochemical methods (mutation, selection). Building on these opportunities and the rapid development of fermentation techniques, the result was a veritable technological revolution. The most important results were the large scale production technologies of antibiotics, amino acids and enzymes.

- The next phase started in the first half of the 1970s. The essence of this new biotechnology is that altering the heritable material of living beings, through a conscious and planned manner, results in the development of new characteristics. Through the use of recombinant DNA and cell fusion, humans begun to alter the characteristics and functions of living organisms to suit their needs.

- The fourth era is linked to the first commercial sale of human insulin (1982). This is the first member of the rDNA pharmaceutical products, meaning the large scale distribution of the products of the previous era. Thus growth gained even more momentum.

- The fifth era can be marked by the latest great innovation, on one hand, the cloning of animals by the use of a cell nucleus, the creation of "Dolly" (1997) and on the other, the completion of the "Human Genome Project" (2000).

Many people see biotechnology as an industry of decisive strategic importance at the start of the 21 st century. According to forecasts, by the middle of the next decade, the pharmaceutical and biotechnology industries will become the leading branches in the world, surpassing information technology and telecommunication. In this article I will only concentrate on red (medical) biotechnology.

The EU considers to develop the biotech industry in view of the pharmaceutical industry exceptionally important. This means strengthening collaboration between the two sectors [4]. Biotechnology plays an increasingly important role in pharmaceutical development, by preventing the onset of and curing previously un-curable diseases through the implementation of new diagnostic methods and treatments. Pharmaceuticals produced through biotech methods, such as proteins, antibodies, enzymes comprised $25 \%$ of pharmaceutical sales in 2003 [5]. Most of the pharmaceuticals currently undergoing clinical trials are biotechnological in origin. The percentage of pharmaceuticals produced using biotechnological methods, is growing rapidly. Of all registered small molecules, significantly more are produced by biotechnological methods, than by synthetic methods (Fig. 1).

These were all changes that radically altered the perspectives and tasks of biotechnology. Main directions of research were shifted, and the map of biotechnology was rearranged by economic factors as well. Therefore these are definitely disruptive innovations. Fig. 2 shows biotechnological knowledge, plotted against a timeline:

Usually, there is a complex, multidimensional, non-linearly correlated uncertainty surrounding disruptive, especially radical innovations, the solution of which often requires cross linked steps. It is important to state, that in terms of management, in opposition to small innovations, the management of radical innovations includes the ability to navigate in sight of unforeseenable events [2].

\subsection{Biotechnology and pharmaceutical companies}

Medical biotechnology is used by two main types of companies. They are either large companies drawing on a long history in the given field and developing into more and more innova- 


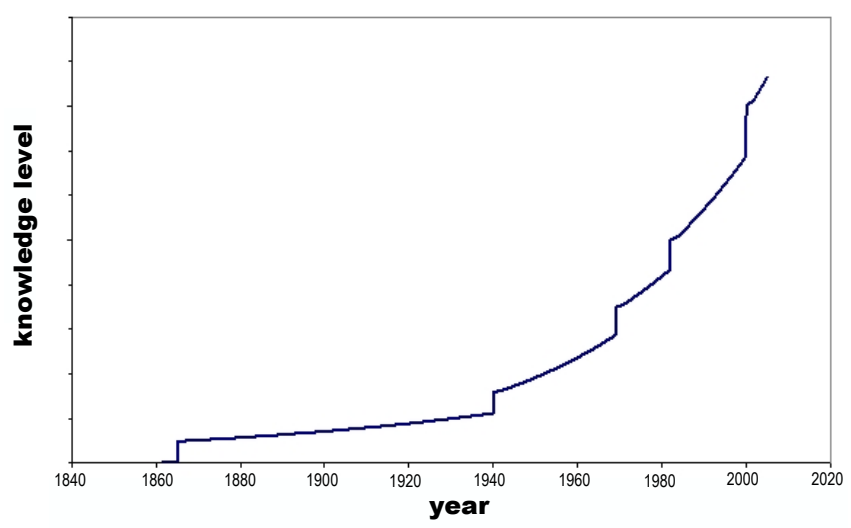

Fig. 2. Changes of the knowledge level in biotech

tive biotechnology users, such as large pharmaceutical companies ("big pharma"). Or, modern biotechnological companies emerge, which the previously stated large companies purchase knowledge, projects or services from. Mainly the large companies control the biotechnology industry with regard to revenue. However this does not lead to strict adherence to traditions and the conservation of states of power. This is because, in terms of knowledge and the number of innovative projects, altogether small biotech companies have the comparative advantage.

Many biotech companies were founded in the 70s and 80s. First they sought to become completely vertically integrated companies, encompassing everything from $\mathrm{R} \& \mathrm{D}$ to production and sales. They used closed innovation only. Gradually, these companies brought new trends in their innovation strategies. At first the companies lacked two things that kept them from reaching their goals: the lack of funds, and experienced managers. However these two things are essential (in addition to technology) for a company to grow from a spin-off enterprise to a large pharmaceutical company. The classic pharmaceutical companies, being on the top that time, already possessed these resources. Thus some of them purchased biotech companies while others however were not open to biotechnology in terms of investment and cooperation [7].

The volume and complexity of biotech and pharmaceutical projects grew in relation to the amount of available information and acquired knowledge in an environment of steadily growing needs for new knowledge. This placed further emphasis on cooperation, the sharing of costs and risks of producing new R\&D results. An industry of high risk benefit type emerged. This led to problems, but opportunities as well. Concerning the problems it was asked: Who will finance the costs of research? Will investors think that the industry is too risky? Naturally the significance of professional investors and specific tenders increased with this.

Companies were forced to cooperate due to the high risk associated with biotechnology, the complexity of strategic management rules and the then unusually high amount of needed funds. First of all, the necessary monetary tools are available only at the largest companies. Second, the necessary competencies are often missing with smaller companies. For example, a smaller company, a market leader in R\&D, does not have the necessary experience either of the capability needed to clinical testing or production. Cooperation is necessary to fill these gaps. With this sharing of different sorts of risks will be realised. These risks, actually non-calculable uncertainties several times, may be technology, market, regulatory or competition related. The later reflects on the segments of all the other risks, since the rapid development of China, South Korea and India. The only advantages can only be quality and knowledge for the traditional pharma producing countries. But precisely these are areas where China and India are developing rapidly, while maintaining the seemingly natural price advantage. Europe and the USA can only compete with these products if they do not count on price advantage, but on therapeutic advantage. This means producing a newer, better molecule, first of all. However this larger added intellectual value brings larger risks on behalf of technological, market and registration. These tendencies are also catalysts of cooperation.

It is precisely these different, yet interrelated risks that make pharmaceutical biotechnology complex. To successfully manage complex processes and instability necessitates cooperation. Instabilities are cross-linked, they can even strengthen or weaken each other. An example of mutual strengthening is the technological uncertainty of producing a new molecule, and the registration and legalization which follow. Registration gives the same molecule an added economical value and can, if it is registered already, decrease market instability, since it can become a market leader, a so called "blockbuster' 1 , with multi million dollar yearly turnover.

Thus instabilities constitute a kind of synergic system. Instabilities are difficult to predict individually, their interrelations are even more so.

Necessity of cooperation can be explained from another point of view as well (Fig. 3). Validity period of a patent is 20 years from the date of application, which, in case of pharmaceuticals can be extended by at most 5 years (SPC). According to Fig. 3 . the product generally appears on the market $13-15$ years after the patent application. With the end of the patent period, one must also count with the appearance of generic and biosimilar products $2^{2}$ Thus there is, at most 10 , but more often only 5 years to cover the entire costs of R\&D and clinical costs and make some revenue. Thus everyone seeks to make the time needed for R\&D as short as possible. One method could be some sort of open innovation, which supports cooperation and outsourc-

\footnotetext{
${ }^{1}$ A blockbuster drug is a drug generating more than $\$ 1$ billion of revenue for its owner each year.

${ }^{2}$ A generic drug (generic drugs, short: generics) is a drug which is produced and distributed without patent protection. The generic drug may still have a patent on the formulation but not on the active ingredient.

Biosimilars or follow-on biologics are terms used to describe officially approved new versions of innovator biopharmaceutical products, following patent expiry.
} 


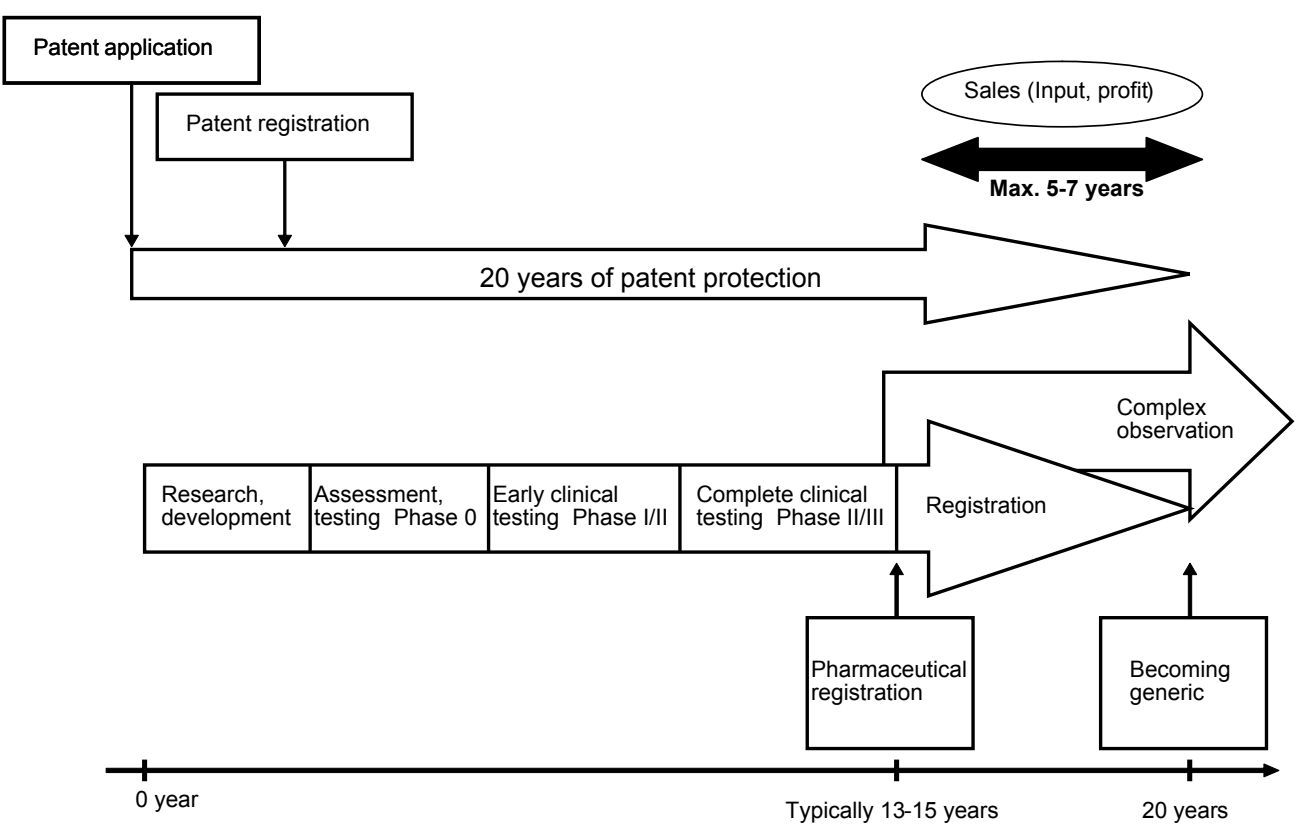

Fig. 3. A typical time-schedule of a new biotech identity

ing instead of solving everything in-house. There are numerous factors which make a part of the R\&D earlier fully integrated in the vertical control target of outsourcing. To shorten the needed time to find a molecule and make it a drug, the steeply growing costs of keeping all the needed expertise within the firm, the decreasing costs of reaching the needed expertise outside, together the transaction costs arguments and the abundance of expertise outside are all for giving advantage to trust R\&D tasks to outsiders who are already experts in the given field. This method definitely saves time and possibly costs as well and systematically open access to better solutions than those available in a "closed innovation" method.

Naturally, in this case, different interests collide. The interest of the originator company as they are called in the pharma industry is to hold on its monopole status as long as possible. This is exactly opposite to the interests of the generic companies, who would like to appear on the market as soon as possible. Consumers are located between the two parties, thus favouring an intermediate approach. They profit from the appearance of generic pharmaceuticals in two ways. Their appearance leads to a decrease in prices, while at the same time, the original companies have to develop new pharmaceuticals, which will be protected from the generic companies for a while. A too short patent period is not good for the consumers, as in this case it will not be profitable for originator companies to produce new pharmaceuticals, or the testing period will not be long, thorough enough, leading to potential hazards.

\subsection{On risks and uncertainties}

The assessment of risks (uncertainties) in the technological development is becoming an increasingly difficult task to solve. This is especially true in a rapidly changing turbulent environment, where environment and its knowledge changes from day to day, where in addition to small ones, radical innovations are typical as well. Understanding the necessary parameters is becoming more and more uncertain, thus also becoming limited. There is a huge literature on technological uncertainty just as there is on risks of financial issues.

My main problem with this is that there is a strong inclination to believe that uncertainty can always be successfully modelled by quantitative risk assessment (qRA). In contrast to this, a wide range of environmental studies puts emphasis on the non-predictable risk. (Think of the management consequence of non-predictability, the needed precaution. $3^{3}$ According to Stirling's model (Fig. 4) we can generate four main groups of uncertainties [8] when taking into account the diminishing knowledge of both the occurrence of events and their frequency. In a more refined system we would have got to differentiate between the events that cause risks and the damages caused by them. This would add two more parameters to the system of uncertainty. (We may not know what can occur as a causing factor AND we may not know what its effect in some environments may be.) But for demonstration of the difference between calculable and non-calculable risk (uncertainty) it is enough to look at a sim-

\footnotetext{
${ }^{3}$ I use the considerations I. Hronszky and -L. Várkonyi in Harvard Business Review [9] referring to Stirling [10].
} 
plified system.

Uncertainty can be interpreted in the following two dimensional systems:

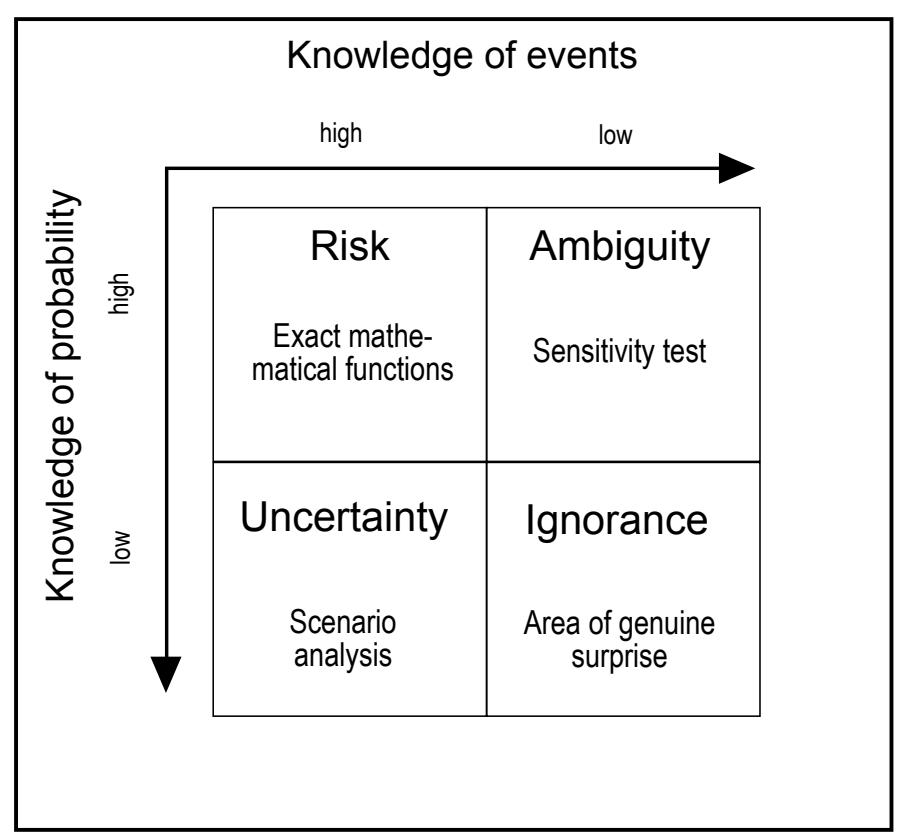

Fig. 4. [8]: Two dimensions of uncertainty

Breakthrough, radical innovations are created under circumstances which lead to genuine surprise. They necessarily imply essential previous ignorance, and result in genuine surprise. To different extents, this is the definition of radical innovations. That is the reason why managing radical innovation, the uncertainty and the unknown, the sphere of ignorance, has a consequence. That is that some sort of trial and error approach, is a key issue. With this we acquire some plausible knowledge about a part of the "previously unknowable" while taking certain interrelations into account. It can be stated that during the evaluation of an uncertain situation partly the "I know that I know" problems should be handled. In this case a deterministic, at least a probability based answer can be provided for. Other problems are of an "I know that I don't know" nature (I know the phenomenon but I don't know the possibility of the occurrence). In this case we can provide plausible answers. The third type is the "I don't know that I don't know" problem, meaning ignorance, already a challenge that both even events and effects are unknown. These are extreme situations e.g. when extreme security requirements are to be realised or outstandingly high profit is searched for. In permanently turbulent environments these questions become the natural questions [9].

Two types of problems emerge in very uncertain situations. First, we literally do not know what can happen (for example by the synergistic effects of known factors and what can the effect be) and second, we do not know the frequency of what happens either. It is most important to see that the main problem with these types of issues is not the calculability with prognostic aim. The problem is the lack of knowledge what can occur at all, the so called lack of ability of modelling.
In terms of biotechnology, uncertainty in the progressing realization of some innovation can be understood more as "ignorance", or "real surprise" for a while. With the accelerating development of biotech industry the domain of "we don't know what we don't know", the range of insufficiently known events and distributions, 'original surprises' is becoming increasingly important, in most cases also accented by irreversibility $94^{4}$ Fuzzy sets considerations can only be part of the solution for these types of issues. At their border "ignorance" is impossible not to take into account if there are reasons that the turbulence is very high.

The lack of the possibility to make reliable risk calculations poses a problem. For example, when looking at the production of pharmaceuticals through genetically modified organisms, producers were faced by problems such of the societal acceptance of the questionable health and environmental consequences of the technology. These concerns resulted in an overall judgment of all technology using recombinant organisms, regardless of their isolation during use. At the same time, "classic" events influencing pharmaceutical production still play a role, such as the merging and cooperation of concurrent companies in the background, as well as the state of industrial rights protection. A new and non-foreseeable problem is the appearance of biogeneric / biosimilar molecules, which generate further uncertainty in the fields of regulation and registration (n-th dimension uncertainty).

Another problem is also possed by uncertainties. In some areas (ex. industrial rights protection, technical realization) certainties are easier to calculate, whereas in others (ex. changes in controls, marketability, price, demand, supply) they are very difficult to approximate. The later are areas which cannot be generalized based on classical examples from the pharmaceutical or chemical industries, they are biotech-specific. Thus there are uncertainties which are unknown. The most difficult task is to incorporate unknown processes when making a decision. Based on this information, when looking at the figure, we can talk about lack of knowledge and real surprises concerning a radical biotechnological innovation.

Based on this we can ascertain that in case of the drastic reduction of knowledge, sooner or later we can begin talking about lack of knowledge instead of uncertainty, since we do not have, in certain cases, we cannot have any information regarding the events to come, not just the frequency of their occurence [11].

Dealing with the role of uncertainty for decision making it is too much told about the risk facts, the analytical level. But decision making unavoidably includes risk evaluation too. It is unfortunate that the risk assessment literature neglects this layer. Following Schwartz and Thompson, and utilizing ideas from lectures of Imre Hronszky and the PhD Dissertation of Ágnes

\footnotetext{
${ }^{4}$ Irreversibility means that two or more surprisingly emerging processes may get into synergistic interrelations that together may make practically impossible the going back to the starting line once again.
} 
Fésüs I shortly demonstrate what with risk evaluation the issue is. Actually at risk evaluation for basic types of evaluating perspectives can be utilized. The Fig. 5 below demonstrates them.

Types of nature represented by different potential curves accepted by the four different types of agents in society, according to Schwarz and Thompson:

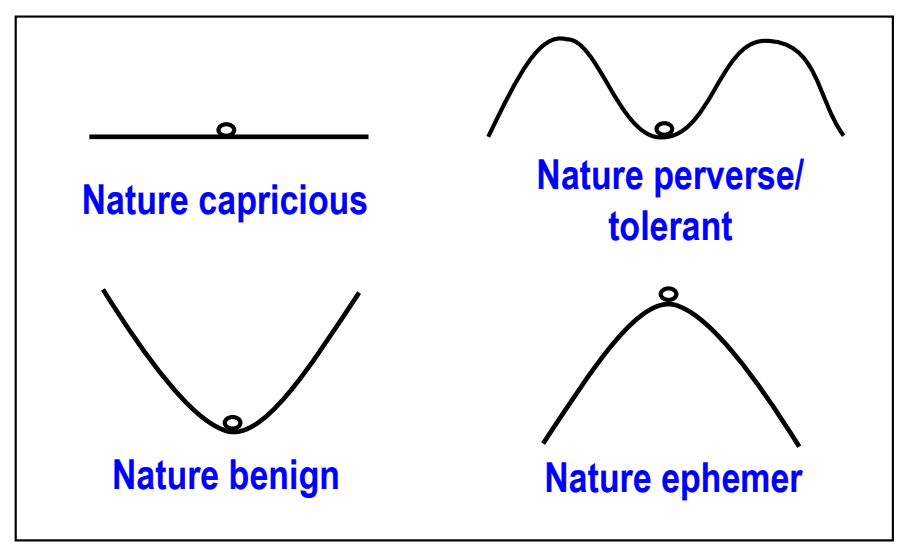

Fig. 5. Four different types of agents in society, by Schwarz and Thompson based on 12]

This means that a real decision is influenced both by factual assessment of risks and evaluation of them, beside genuine management and communication considerations.

\subsection{The results of uncertainty}

According to Fig. 4, when trying to manage the areas of "ignorance" and "real surprise" large and small biotech companies undergo a sort of evolutionary change. Not all large companies undertook the task of looking for and using the newest discoveries in biotechnology with their own resources. They deem these projects too risky, or a large and well situated company may not be motivated enough to jeopardize its comfortable status. Smaller companies, spin-off enterprises and biotech organizations on the other hand are forced to develop and use the new, and thus risky technology, since this is their only way of competing with large companies.

Recently, biotech companies entered the early phases of research, selling their products, ideas and results to pharmaceutical producers [13]. These companies were small. Therefore they could not even think about producing their own product. Selling their knowledge was something they could realize. Many of them went bankrupt, were not successful, but there were those that survived this early phase [14].

Large pharmaceutical companies usually purchase finished molecules, before or after the $2^{\text {nd }}$ clinical phase 5 from the small

\footnotetext{
${ }^{5}$ Phase I trials are the first stage of testing in human subjects. Normally, a small group of healthy volunteers will be selected. This phase includes trials designed to assess the safety, tolerability, pharmacokinetics, and pharmacodynamics of a drug.

Once the initial safety of the study drug has been confirmed in Phase I trials, Phase II trials are performed on larger groups, and are designed to assess how well the drug works, as well as to continue Phase I safety assessments in a larger group of volunteers and patients.
}

biotech companies. This means that with the technological development is already some win-win situation realized this way. Big companies reduce their risks, which however still remained considerable, even in this phase, but at the same time the cooperation with the smalls allow small biotech companies to prosper. New forms, new players were formed. CMO units (contracted place of production) for example, CRO organizations (contracted research unit), consulting and service companies. In other words the organizations share the risk, the same way they share the work and the income.

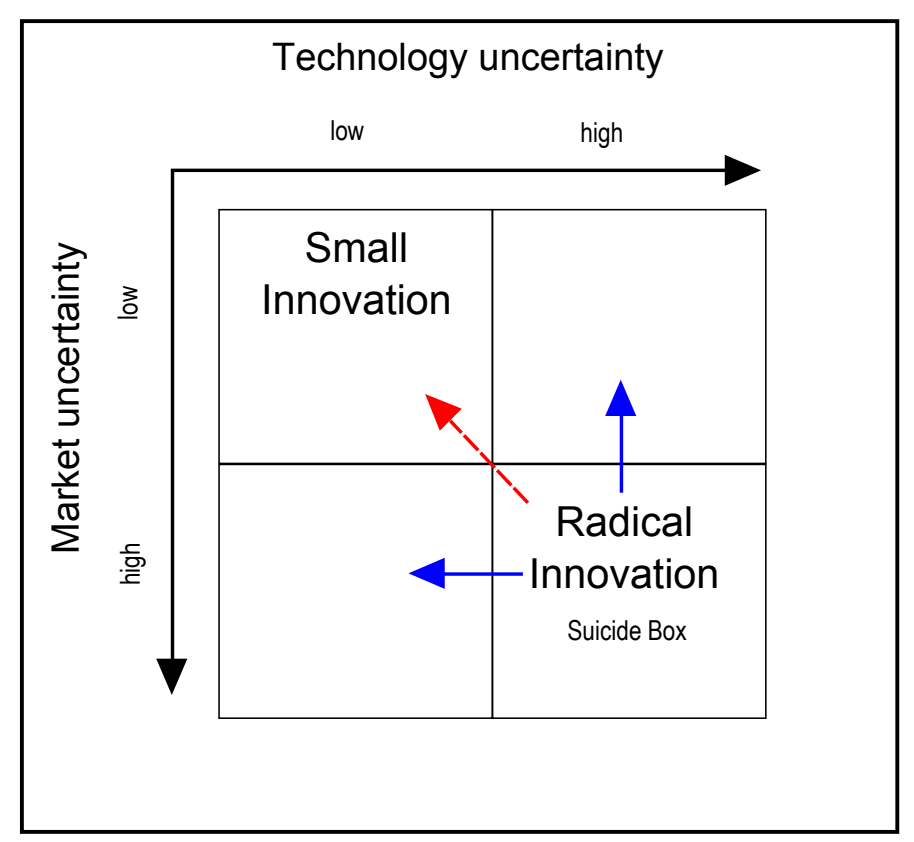

Fig. 6. The risk sharing process, based on [9] (modified by the author)

Fig. 6 shows the risk sharing process. By their nature, completely new biotechnological projects, aiming at radical innovation, originally fall into the "suicide box". They are characterized by high market and technological uncertainty. In a given situation, a small biotech company, since it has no other choice, working out the right technology, sells it to the larger pharmaceutical company. From the point of view of the big company, the technological uncertainty is reduced considerably, since it is purchasing a technology that has been proven to work. (The technology is over the proof of the concept phase). The market uncertainty remains now to solve, which can be assessed and estimated by the purchaser. Another extreme case is when a small innovative company tries to become a supplier for one of the large market players. Trying to meet its needs, perhaps even relocating closer to the purchaser, is thus reducing market uncertainty for both parties. Thus the reason for cooperation is to decrease at least one, but preferably both (marked by dashed

Phase III studies are randomized controlled multicenter trials on large patient groups and are aimed at being the definitive assessment of how effective the drug is, in comparison with current 'gold standard' treatment.

Phase IV trial is also known as Post Marketing Surveillance Trial. Phase IV trials involve the safety surveillance (pharmacovigilance) and ongoing technical support of a drug after it receives permission to be sold. 
arrow) uncertainties. By sharing the associated risks, the organizations will not be able to reach the small innovation level, as this is not the goal of the cooperation. But at least they can decrease risk somewhat.

Large companies (at first in Japan, then in the USA) decreased their in-house activities by focusing more on outsourcing, thus becoming faster and viable. The role of innovation has increased, it has become the main weapon of small knowledge oriented organizations that are closely linked to universities. This way of organizing innovation made it necessary for large companies to change their strategies, becoming faster and rethinking their risk assessment. When looking at the pharmaceutical industry, large companies are becoming more and more dependent on the original discoverer of the pharmaceutical molecule, on the small biotech companies. But this changed relationship is beneficial for both parties. Cooperation with a large pharmaceutical company guarantees company's growth and long life. Cooperation is also supported by the pharmaceutical manufacturer, since the fastest and least risky method of acquiring innovation and holding onto strategic advantages is building from the outside [15].

\section{Strategies of biotech companies}

\subsection{The issue of R\&D structure}

The organisational structure, or "anatomy" of the biotechnological R\&D sector is a key issue. The anatomy is composed of the sector's direct participants (spin-off companies, other enterprises, R\&D laboratories, universities, pharmaceutical companies) and the institutions that connect them (capital markets, intellectual property protection). For the complete success of biotechnology, anatomy is bound to further the participants to excellent performances in three fields:

- risk taking, risk management and risk rewarding,

- integrating and rapidly mastering knowledge and abilities that reside in different disciples and functions,

- improving knowledge of critical importance on both structural and industrial levels.

The industrial structure (anatomy) is supposed to be consistent, its parts are supposed to help and support each other, they are supposed to meet challenges.

In biotechnology aims seem to contradict each other. For instance, industry finances business (evaluates risk), which contradicts the laborious R\&D work needed for the development of new pharmaceuticals. The diversification of the industry and the small, but largely specified mass of participants involve the formation of islands of specialized knowledge, which prevent knowledge integration. Furthermore, intellectual property market, where companies can provide right to use scientific achievements, limits the number of researchers who can improve this knowledge by learning from experiments and failures.
Before biotechnology appeared, science and industry had not or to a much less extent been mixed in the classical pharmaceutical industry. Experiments conducted in order to extend scientific knowledge had belonged to universities, state laboratories, nonprofit research centres. Only a few big companies carried out cutting-edge research, but these were unique ones. Biotechnology connected the two fields and created a new scientificbusiness model. Universities' and biotech companies' borders merged. Many companies are founded at universities (spin-off), employees belong to both of them and they often share their means too.

Genentec worked out a model for making money of intellectual property in biotechnology, which greatly affected the present operation of biotechnology, and proved its viability in the practice. The model contains three interacting elements [16]:

- technology transfer from universities to the private sphere, through establishing new companies instead of marketing to existing companies

- risk capital and share markets, which provide financing in critical times and reward risktakers

- expert market, where new companies give intellectual property to old companies in return for financing.

The anatomy of biotechnology is not optimal at present. It is like other high-tech sectors, such as IT. It involves new ventures with university background, which focus on certain elements of the R\&D value chain. Furthermore, anatomy consists of capital and share markets.

This structure is based on the approach that biotech will be like other innovative, high-tech industries. In fact, three major differences are present:

- great and permanent uncertainty, which can be traced back to the unknown nature and n-th dimensional uncertainty of systems and processes, risking e.g. pharmaceutical development to a great extent.

- The R\&D elements of a pharmaceutical (links of the value chain) cannot be separated from each other, involved disciplines and organisations have to cooperate very closely.

- The knowledge of companies in the pharma-biotech sector is mainly intuitive or tacit, which makes the exploitation of collective knowledge and cooperation difficult.

As a consequence of the above mentioned, a better anatomy exists, or at least may theoretically exist, which has to be or should be followed by companies of the sector in order to optimally exploit collective knowledge. In general it can be said that in the extremely risky and innovative, yet outstandingly high risk-high benefit biotechnology methods and anatomy have to be different from the also innovative IT tools and construction.

The vertical nature of integration should be enhanced. This requires a critical size, thus the big pharma companies have to 
be the integrators. This means that the inner structures have to be changed. Cooperations are still of great importance, but closer, more strategic cooperations are necessary. I tried to demonstrate already earlier in theis article that it is clear that even the biggest companies cannot manage their entire R\&D alone, division, strategic division of labour is needed. Strategic divisions of labour (e.g., carrying out basic research focusing on one costumer) are more efficient than some occasional cooperation. These cooperations are generally long-term ones.

This strategic approach characterises biotechnology companies as well. Still a lot of small spin-off companies are needed, because they are the first essential institutional element of the innovation chain. It is rather the big, independent, non-project companies, the number of which may be decreased with further evolution of the learning of the good strategies for biotech companies research activities.

Research can less and less be divided into disciplines. It is more of a comprehensive nature, because biotechnological innovations may not only have biotech and medical, but also mathematical, chemical, physical and IT aspects. As a result, the role of interdisciplinary projects is increasing.

Consequently, cooperations have to be laid on new foundations, they have to be stabilized and made dynamic at the same time $[16] 6$

\subsection{A possible survival strategy for biotech companies:} "protected market companies"

A biotech company must gain some sort of strategic advantage on the competition. This can be accomplished in two ways: the realisation of the product/service can either be less expensive by cooperation than by competition or leads to better product/service. A special form of the later is when a product does not have a direct competitor. Naturally, a smaller biotech company can break into some smaller market segment. This is how so called "niche-companies" are formed. In addition to cooperation, this is one of the survival strategies of beginning biotech companies.

What exactly does a protected area (niche) mean? It can be described as a protected region, a new market opening or a protected segment. Of course there can be a market "gap" as well, a segment where competition is not active. In my opinion this can also be a technological gap, or segment.

From the point of view of the market, a niche market is a well defined smaller segment of a larger market. To say well defined, is important, since this is what the company will be "labelled" by. A single focus guarantees efficiency. Knowledge, information and innovations will not branch out, thus guaranteeing efficient operation. The small size of the segment also provides protection, it is important to choose an appropriately tight segment. It must be large enough for the company to survive and

\footnotetext{
${ }^{6}$ I rely in this chaper on the considerations of Pisano (Can Science Be a Business?), Harvard Business Manager, October 2006.,114-122 heavily.
}

grow according to plan, but too small, non economical for large companies to enter. A possible "exit" strategy for biotech companies is demonstrating that the given segment is not as small as it was previously thought, thus gaining the interest of large companies. Of course, the right IP strategy and technology is needed for this sort of success.

At the same time it is important to assess whether the market gap is large enough. What is the size of the market that will purchase our product or services?

At the same time, the company must possess very specific knowledge in these specific markets. This may mean actual knowledge, or skills, which include the necessary equipment, tools and contacts. These may be very difficult to reach, requiring problem solving skills and further development. Due to the small size of the market, these may require specialized solutions, acquiring these can be more costly, in some cases many times more costly than generalized solutions. This must be assessed when mapping the market. Furthermore it means an exceptional learning skill is required related to a small focused field.

In my opinion the protected niche technology can only be defined along with the niche market, as they are always closely linked. In practice it refers to technology, tools, molecules or solutions developed for a specific market segment. This guarantees its novelty and individuality. It is important to reach critical mass. Will the company be able to reach a large enough percentage of the protected market? It is also a potential advantage if the solution can be expanded into broader markets. At this point I would like to emphasize industrial rights protection.

Companies associated with specialized, protected markets or technology, have their advantages (+) and disadvantages (-):

+ defined goal, concentration of resources

+ new, unique technology, service, knowledge

+ a smaller company is able to reach critical market mass

+ in case of the right market, an exceptionally valuable product can be produced

+ close ties form with other players of the small market

+ a market that is relatively protected from competition

- small market, or in some cases, no market at all, since the given company generates its own market, (the marketing of innovation)

- it is difficult to find the right market and consumers

- a possible lack of sales channels, perhaps the critical mass is not met

- the company may be very sensitive to changes in the given niche.

Survival is possible if the niche company can become the market leader (in the given market). At this point it can even 
compete with a multi billion dollar pharmaceutical company, since the targeted market is different, the amount of profit is not enough to motivate a large company. A large company will concentrate on areas where it can best use the advantages of its size and economic power. Generating and defining a market gap, then developing into it, most likely represent a larger risk, than operating in existing markets.

A small niche company is dependent on different partners, due to the nature of the gap. Very often these developments do not have any precursors, so they require completely, or partially new technology, which is often too complex for a small company. A small company needs grants, tenders and other outside support. Collaborations, consortiums and clusters all help in acquiring this support. Collaboration makes research less expensive, thus critical mass is easier to reach.

\subsection{On the evolution of the collaboration between biotech-} nological and pharmaceutical companies

Just as in all other newly emerging industries the presence of small specialized companies, profiting from cooperation and clusters is significant. From this point of view, biotechnology is similar to telecommunication, information technology and the media. The large pharmaceutical company controls the finances of cooperation, even though it only takes part in the real work after Phase 2, or Phase 3. This way the large company becomes dependent on the small companies who provide the technology and knowledge, since it builds on them, investing into markets and production potential. It is more economical for it to spend a portion of the budget on supporting smaller companies and cooperation, than to finance broad R\&D. Biotechnological cooperation is characterized by the inequality of power amongst the participants.

Biotech companies often sub-contract production, marketing and sales to a large pharmaceutical company. When they do this, they have already reached a certain minimum result or size, which means a risk reduction for large pharmaceutical companies.

The reason for merging is important changes in the knowledge-generation, which has a very dynamic effect on this industry and its specific institutions. Evolution can be described by a two step process. Due to specific knowledge and through scientific research centres biotech and pharmaceutical companies are linked very closely, closer than other branches of industry.

The change from old to new biotechnology came about thanks to financial investors, who were convinced in the success of new university spin-off enterprises. Many favourable forecasts were made based on the prevention of infectious diseases, extrapolated to genetic illnesses. Many large companies and investors sought to cease this opportunity, thus start-up companies were the center of attention. Expectations were confirmed by the human insulin project (Genetech, 1979).

The first successful companies changed the type of growth of the industry, just as they changed the vision of business. Despite their successes, these companies had their weaknesses. They were headed by university, academic personnel, who did not identify the issue first of all as business but as an invention process. Investors changed this, putting the overall conceptualisation in the hands of businessmen, and leaving the scientist responsible for the technology, only. As a result many of these companies made it then to the stock market. Companies without financial investors crumbled and went bankrupt. Thus investors functioned as a sort of selection pressure.

The second wave of growth occurred at the end of the 1990s, when economic potentials were ready for the introduction of new research, the focus was placed on the analytical understanding of work with living organisms. The knowledge of sequencing of genomes (ex. human genome project) greatly and emblematically influences the further areas of development in biotechnological and pharmaceutical research. This second wave was interdisciplinary to a large extent, combining the knowledge from different, complementary fields (chemistry, biotechnology, material studies, mechanics and computing). These interdisciplinary studies between organizations brought about new industrial activities and cooperation. Small biotech companies played a different role, becoming discoverers and introducers of new techniques, generating input for large pharmaceutical companies [17]. Thus cooperation between a small biotech company and a large pharmaceutical company resulted in a competitive advantage in the already very competitive pharmaceutical industry. Many small companies remained cooperating outside units, where as others merged into the large companies.

I refer from the literature to Garnier (Rebuilding the R\&D engine in Big Pharma) [18]. In the case of GlaxoSmithKlein, the management realised in the late 1990s that their organisational pyramid had become obsolete. Until then, in accordance with the principle of closed innovation, we can say exaggeratedly that they had been just a great R\&D unit with general scope of duties. They aimed at establishing more specific units, delegating competencies, making $R \& D$ processes faster and more flexible. As a consequence, they divided the former units into smaller R\&D units with different focuses, which allowed group leaders more freedom and a really relevant knowledge [18].

Knowledge plays an increasingly important role in survival. Naturally large companies use the knowledge of their partners as well. Due to cooperation, some large company - small company alliances managed to survive, marketing new molecules and breaking into new areas of technology. Large companies are at an organizational advantage, they have broader market contacts, they are better off financially, they can realize larger outside investments and they have more experience. These are all factors, which smaller companies cannot reach on their own. The advantages of smaller companies are: faster adaptation to a changing environment, more willingness to undertake new projects, increased personal attention to detail, more personal 
contact with customers.

These days the visible tendency is for certain biotechnology companies to establish long lasting strategic cooperation with a certain pharmaceutical company. Thus the biotech company develops its portfolio, its importers so that its products will meet the requirements of the large company comprising its market. In some cases the topics and ideas come from the pharmaceutical company. Thus the importers of knowledge are becoming increasingly more specialized. Naturally these interrelations do not mean exclusivity. New companies and results are emerging all the time, new interactions can occur alongside these interrelations.

This is a knowledge intensive sector. New procedures, discoveries and procedures appear, the knowledge needed to survive changes rapidly. The $R \& D$ costs needed for acquiring the necessary knowledge are high, however if companies do not follow the changes in technology, they have no chance of long term profit.

What does this mean? The largest biotechnology companies can invest lots of resources in $R \& D$ and reap its benefits. There are several of these companies in the USA, a few in Europe and very few ( if any... ) in Hungary.

Thus reaching critical mass is out of question. Thus it is necessary to develop some sort of interaction (network) between companies which is a sort of "division of labour".

During the fight for survival and growth, formal and informal cooperation, strategic and interest alliances are formed. A company's success in biotechnology requires three different competencies: strong management, financial resources, good technology. Strong management is the most important factor, since it will be the one who will be able to acquire money and oversee research directives. However suitable resources and technology alone is not enough for success, since in biotechnology strategies the novelty of the product is more important than its price advantage. Technology requires a considerable investment, well before it can generate any revenue.

\section{Summary}

As we have seen in biotechnology, just as in other rapidly evolving branches of industry, changes are very fast, the increase of knowledge is exponential. Since this industry is of very high risk ("high risk - high benefit"), and these risks are in great measure non-calculable uncertainties, and since R\&D phases may require several hundred million dollars, the participants seek to minimize and share risks. Small biotech companies can follow two strategies for staying alive: finding a protected market segment where, with the help of outside resources they can become definitive, or by concentrating on cooperation, taking on smaller tasks, becoming an importer of knowledge as a member of a cluster. These special solutions, as I have shown, work in biotechnology.

\section{References}

1 Buzás N, Lengyel I, Ipari parkok fejlődési lehetôségei: regionális gazdaságfejlesztés, innovációs folyamatok és klaszterek., JATEPress, 2002.

2 Domonkos D, Az innováció terjedésének lehetoségei a biotechnológiai iparban, Mûszaki Kémiai Napok (Veszprém, 2006), 2006.

3 Frigyesi V, Nyeste L, A biotechnológia fejlödésének "történelme” és hatásai., Valóság, 44(11), (2001).

4 Bod E, Buzás N, Fehér A, Holló Z, P’al Á, A high-tech technológia különös tekintettel a biotechnológiára - fejlesztési feltételek kialakítása Magyarországon, Tanulmány a Gazdasági és Közlekedési Minisztérium megbízásából, 2004.

5 Schmidt F, Recombinant expression systems in the pharmaceutical industry, Applied Microbiology and Biotechnology, 65(4), (2004), 363-372, DOI 10.1007/s00253-004-1656-9

6 Datamonitor, Biosimilars: Benchmarking the Key Players. With increasing regulatory clarity and high revenue potential, interest in biosimilars increases, 2006, available at http://www.datamonitor.com/

7 Murray F, Innovation as co-evolution of scientific and technological networks: exploring tissue engineering, Research Policy, 31(8-9), (2002), 1389-1403, DOI 10.1016/S0048-7333(02)00070-7.

8 Stirling A, Precaution, Foresight and Sustainability: Reflection and Reflexivity in the Governance of Science and Technology. Reflexive Governance for Sustainable Development, Reflexive Governance For Sustainable Development (Voß J, Bauknecht D, Kemp R, eds.), Edward Elgar Publishing, Celtenham, UK, 2006, 2006, 225-272.

9 Hronszky I, Várkonyi L, Radikális innovációk menedzselése, Harvard Business Manager Review, 50(10), (2006), 28-41.

10 Stirling A, On Science and Precaution in the Management of Technological Risk, Vol 1., Luxembourg, 1999. EU DG Research, Joint Research Centre, Institute of Prospective Techniological Studies.

11 Cooke P, Biotechnology clusters, 'Big Pharma' and the knowledge-driven economy, Int. J. Technology Management, 25(1-2), (2003).

12 Schwarz M, Thompson M, Divided we stand: redefining politics, technology, and social choice., University of Pennsylvania Press, Philadelphia, 1990.

13 Mark R., Smith A, Corridor Biotech 'Cluster'? It Could Happen, 2006.12.15, available at http://209.116.252.254/7_2003_focus/f_ 2.html

14 Lemariés S, Mangematin V, Torre A, Is the Creation and Development of Biotech SMEs Localised? Conclusions Drawn from the French Case, Small Business Economics, 17(1-2), (2001), 61-76, DOI 10.1023/A:1011197616151.

15 Persidis A, President V, Biotechnology clusters, Drug Discovery Today, 4(7), (1999), 297-298.

16 Pisano G, Can Science Be a Business?, Harvard Business Manager, (2006), 114-125.

17 Pyka A, Saviotti P, Innovation Networks in the Biotechnology-Based Sectors, Discussion Paper Series, Edward Elgar Publishing, 2002.

18 Garnier J-P, Rebuilding the RED D engine in Big Pharma, Harvard Business Manager, (2008), 68-76. 